\title{
PENELITIAN KUALITATIF DAN KUANTITATIF
}

\section{A. Pendahuluan}

Peneliti dituntut kepekaan dan kemauannya untuk mendapat jawaban secara ilmiah terhadap berbagai masalah dalam kehidupan masyarakat. Sebelum melaksanakan penelitian, peneliti dibekali dengan berbagai pengetahuan dan keterampilan serta teori-teori sesuai dengan bidang kajian yang ditekuninya. Istilah metodologi (methodology) dengan metoda (methods) tidak jarang tumpang tindih penggunaannya. Sebenarnya metodologi (methodology) merupakan studi yang logis dan sistematis tentang prinsip-prinsip yang mengarahkan penelitian ilmiah, yang intinya terdiri dari : masalah, tinjauan pustaka, kerangka teori (jika ada), hipotesis (jika ada) dan cara penelitian. Sedangkan metoda (methods) merupakan cara untuk melakukan penelitian, menyangkut dengan bahan, alat, jalan penelitian, variabel penelitian dan analisis hasil.

Metoda penelitian pada prinsipnya menceritakan cara yang merupakan alat (tod) mencapai tujuan. Cara yang dilakukan dalam penelitian bervariasi dan tidak kaku serta tergantung dari objek formal ilmu pengetahuan tersebut, tujuan serta jenis data yang akan 
diungkapkan. Penelitian umumnya mengandung dua ciri, yaitu logika dan pengamatan emperis (Babbie, $1986: 16$ ).

Penelitian ditujukan memecahkan masalah yang dihadapi untuk pengembangan ilmu pengetahuan dan permasalahan umat manusia. Jawaban masalah tersebut menggunakan pendekatan ilmiah (scientific approach) yang pada gilirannya melahirkan metode ilmiah (scientific method). Upaya yang dilakukan dengan menggunakan metoda ilmiah disebut dengan penelitian ilmiah (scientific research).

Penelitian ilmiah adalah suatu bentuk upaya penyelidikan (investigation) terhadap suatu pernyataan (proposisi) hipotesis yang dijadikan sebagai jawaban sementara suatu masalah. Membedakan dengan bentuk penyelidikan lain, ada beberapa ketentuan pokok yang harus dipenuhi oleh pelakunya, Pertama, penelitian itu harus dilakukan secara sistematis, terkontrol, dan kritis. Kedua, penelitian ilmiah menghasilkan kebenaran ilmiah, bersifat menerangkan (explanatory), memprediksi (predictive) dan mengontrol (controlling).

Penelitian ilmiah adalah kegiatan yang bersifat indrawi (empirical) maksudnya, jawaban masalah yang diperoleh melalui kegiatan ini merupakan keyakinan subyektif peneliti namun telah teruji dengan kenyataan-kenyataan objektif di luar dirinya. Dengan kata lain, setiap 
pernyataan peneliti haruslah selalu didasarkan pada kebenaran yang diperoleh melalui pengujian dan penjelajahan yang bersifat empiris (empirical inquiry and test).

Keyakinan terhadap jawaban suatu masalah memerlukan upaya pengujian di luar dirinya sendiri. Dengan kata lain sesuatu yang dianggap benar secara subyektif dan teoritis perlu diverifikasi seberapa jauh kebenaran yang diduga itu ditemui pada kenyataan objektif (objective reality) di lapangan. Bila proposisi hipotesis-teoritis itu didukung oleh data yang ditemukan di lapangan barulah proposisi itu diterima sebagai jawaban masalah secara relatif meyakinkan. Namun bagaimanapun juga temuan tersebut masih tetap terbuka untuk diujikan lagi pada kesempatan lain. Barulah kemudian setelah menempuh ujian berkali-kali, proposisi tersebut dapat dijadikan sebagai teori keilmuan yang baru. Karena itu tidak mustahil temuan suatu penelitian akan ditolak oleh data pada kesempatan lain. Bila terjadi demikian maka kemungkinan tertolaknya temuan yang semula diharapkan akan menjadi unsur baru khasanah pengetahuan tidak dapat dihindarkan.

\section{B. Paradigma dalam Penelitian Kualitatif dan Kuantitatif}

Secara umum penelitian dibagi atas dua jenis, yaitu penelitian dasar (basic research) dan penelitian terapan (applied research). 
Penelitian dasar merupakan penyelidikan terhadap sesuatu objek karena keingintahuan, kepedulian peneliti dan penerapan terhadap penemuan tidak menjadi prioritas utama. Sedangkan penelitian terapan atau penelitian praktikal merupakan penyelidikan yang sistematis, terus menerus terhadap suatu masalah dengan tujuan praktis dan hasilnya dapat dimanfaatkan untuk tujuan tertentu.

Metode penelitian sebagai alat untuk mencari jawaban terhadap pemecahan permasalah menggunakan pendekatan kualitatif dan kuantitatif. Kedua pendekatan tersebut menggunakan paradigma yang berbeda. Imran Manan (1993:1) menjelaskan paradigma positivistik menggunakan metodologi kuantitatif dan paradigma naturalistik menggunakan metodologi kualitatif.

Paradigma positivistik berkembang di Perancis dan Jerman pada Abad 19 seperti tercermin dari karya John Stuart Mill berjudul " $A$ System of Logic" terbit tahun 1843. Stuart Mill mengemukakan asumsi dasar sebagai berikut : (1) ilmu sosial dan ilmu alamiah mempunyai tujuan yang identik, yaitu menemukan hukum-hukum umum yang berguna untuk penjelasan gejala alam untuk meramalkan peristiwa-peristiwa, (2) ilmu sosial dan ilmu alamiah memiliki metodologi yang identik, (3) ilmu-ilmu sosial lebih komplek dari ilmu alamiah, (4) konsep-konsep dapat 
didefinisikan dari referensi langsung kategori-kategori empiris yaitu objekobjek yang kongkrit, (6) uniformitas alam dalam hal waktu dan ruang, (7) hukum-hukum alam secara alamiah atau secara induktif diperoleh dari data, (8) sampel yang besar mengurangi keanehan (ideosincrasy) dan akan menggungkapkan sebab-sebab yang umum (hukum alam).

Penerapan asumsi positivisme telah mendorong perkembangan ilmu alamiah, namun penerapannya di bidang ilmu sosial menimbulkan kritikan. Imran Manan (1993:3) menjelaskan salah satu kritik mendasar yang dikemukakan Lincoln dan Guba berhubungan erat dengan asumsi dasar positivistik yang sukar dipergunakan dalam bidang ilmu-ilmu sosial. Kelima asumsi dasar itu adalah : (1) asumsi ontologis yang menganggap hanya ada satu realitas nyata yang dapat dipecah-pecah menjadi bagianbagian yang dapat dikaji secara independent; keseluruhan merupakan penjumlahan bagian-bagian, (2) asumsi epistimologis tentang kemungkinan pemisahan antara pengamat dengan yang diamati, (3) asumsi tentang independensi temporal dan kontekstual dari pengamatan, sehingga apa yang benar pada satu waktu dan tempat, dengan keadaan yang cocok, akan juga sama di waktu dan tempat yang lain, (4) asumsi kausalitas yang bersifat linier, tak ada akibat tanpa sebab dan tak ada sebab tanpa akibat, (5) asumsi aksiologis menyangkut bebas nilai, yaitu 
metodologi yang ilmiah akan menjamin bahwa hasil suatu penelitian seyogianya bebas dari pengaruh sistem nilai (Lincol and Guba, 1985:28).

Lebih lanjut Imran Manan (1993:3) menjelaskan karena kelima asumsi dasar tersebut tidak tepat digunakan dalam bidang ilmu sosial, disebabkan hakekat objeknya berbeda, maka aksioma yang menjadi paradigma dari penelitian naturalistik diperlukan paradigma baru, yeng merupakan paradigma pasca-positivistik, dengan asumsi (1) argumen hakekat perilaku penelitian yang menunjukkan peneliti tak dapat menggunakan model yang berbeda bagi dirinya dengan model bagi yang ditelitinya, (2) argumen intensionalitas (maksud) yang menunjukan perlunya pengecekkan maksud-maksud yang ada pada subjek yang diteliti dengan interpretasi yang dibuat oleh peneliti, (3) argumen bahasa menunjukan peneliti harus sama dengan bahasa dari yang diteliti, (4) argumen epistimologi yang diperluas menunjukkan proses penyelidikan ilmiah melibatkan tidak hanya pengetahuan proposional, tetapi juga pengetahuan praktis dan pengetahuan pengalaman, (5) argumen aksiologi menunjukkan kebenaran sebuah proposisi tergantung pada nilai yang disepakati bersama dan argumen moral dan politik. 
Perbedaan paradigma penelitian kuantitatif dengan kualitatif menyebabkan perbedaan proses penelitian yang dilaksanakan dari kedua pendekatan tersebut.

\section{Penelitian Kualitatif}

Penelitian kualitatif disebut juga naturalistic inquiry memandang realitas sosial bersifat unik antara satu dengan lainnya sehingga sulit untuk melakukan generalisasi tentang keseluruhan kalau hanya didasarkan sebagian. Oleh karena itu pemahaman keseluruhan diperlukan pendekatan holistik. Pernyataan tersebut ditentang oleh peneliti kuantitatif dengan argumen walaupun setiap bagian mempunyai keunikan tersendiri akan tetapi ada beberapa karakteristik memiliki kesamaan dan dimungkinkan untuk dilakukan generalisasi. Apabila realitas sosial telah dapat diungkapkan berdasarkan beberapa penelitian mencukupi maka prediksi terhadap suatu fenomena sosial dapat dilakukan dari pada hanya berdasarkan kebetulan.

Berangkat dari perbedaan kedua pendekatan tersebut, Gall dan Borg (1989) mengemukakan beberapa perspektif dalam menerapkan penelitian sosial, meliputi :

1. Reseach involves holistic inquiry carried out in a natural setting, dengan maksud bahwa suatu penelitian diharapkan bersifat 
menyeluruh untuk dapat menjelaskan suatu fenomena serta situasi penelitian tidak diintervensi peneliti.

2. Human are the primary data-gathering instrument, hal ini menunjukkan bahwa peneliti sebagai alat pengumpul data yang terpercaya dari sekedar instrumen berupa tes, inventory atau kuesioner.

3. Pusposive rather than random sampling, menjelaskan bahwa pemilihan subyek penelitian tidak dilakukan secara random akan tetapi didasarkan kepada tujuan tertentu. Sehubungan hal itu variasi informasi yang dikumpulkan ditemukan dan informasi yang terbuang dapat dihindarkan.

4. Inductive data analysis tidak didasarkan dengan hipotesa yang telah ditentukan sebelumnya, akan tetapi lebih difokuskan untuk memahami data serta selanjutnya mengambil suatu kesimpulan.

5. Development of grounded theory, yang bermaksud bahwa teori dikembangkan berdasarkan data lapangan dan tidak dengan teori yang telah ada sebelumnya membatasi diri peneliti dari berbagai kemungkinan yang terjadi berdasarkan data.

6. Design emerges as the research progress, desain dengan sendirinya muncul bersamaan dengan pelaksanaan penelitian. Oleh karena itu 
peneliti tidak perlu membuat suatu rencana (desain) pada saat akan melaksanakan penelitian.

7. Subjetc plays a role in interperting outcomes, maksudnya interpretasi terhadap temuan bukan merupakan prerogatif peneliti semata akan tetapi interpretasi dari subyek penelitian dapat mempunyai arti penting dalam proses menginterpretasikan temuan.

8. Utilization of intuitive insight menekankan kepada peneliti tidak hanya berdasarkan pertimbangan-pertimbangan rasionalistik tetapi juga pertimbangan intuitif. Intuisi dapat memberikan suatu ilusi yang lebih memperjelas fenomena yang sedang diteliti.

9. Emphasis on social process, proses sosial memberikan arti terhadap hal yang berkaitan dengan situasi sosial tertentu. Pada gilirannya pemahaman makna secara holistik dapat diungkapkan.

Perbedaan yang mendasari antara kuantitatif dengan kualitatif menyebabkan metode yang digunakan dalam mengumpulkan data juga berbeda. Borg dan Gall (1989) mengemukakan ada empat jenis metoda yang dapat digunakan, yaitu :

\section{Participant observation}

Penggunaan metode ini menunjukkan peneliti bagian dari subjek yang diteliti dengan mengkaji berbagai informasi selengkap 
mungkin dari berbagai aspek kehidupan subyek yang diteliti. Hal ini sesuai dengan asumsi penelitian kualitatif bahwa proses sosial merupakan bagian dari temuan penelitian. Dengan partisipan observasi peneliti akan menemukan apa yang terjadi di balik apa yang nampak di permukaan.

Hal yang perlu diperhatikan dalam observasi adalah (1) pengamat harus memiliki fokus, (2) dalam membuat catatan lapangan kata sifat interpretatif, seperti, menyenangkan , cantik, menarik harus dihindarkan. Interpretasi dilakukan pada tahap penulisan dan bukan pada tahap pengumpulan data, (3) kehadiran peneliti selama pengamatan tidak mengganggu kehidupan keseharian subyek yang diteliti.

\section{Non-participant observation}

Salah satu kelemahan dari metode partisipan observasi adalah sulitnya menghindari keterlibatan emosi peneliti terhadap subyek yang diteliti, sehingga keterlibatan tersebut menyebabkan bias terhadap data yang diungkapkan. Menghindari hal tersebut dikembangkan metode non-partisipan observasi. Menggunakan metode ini maka data yang terkumpul adalah data behavioral dalam arti hasil pengamatan terhadap prilaku subyek yang diteliti, bukan 
pendapat dari subyek yang sedang diteliti. Salah satu karakteristik metode non-partisipan ditunjukan oleh tidak terdapatnya interaksi dan komunikasi dengan subyek yang diteliti. Informasi lain yang dapat dilengkapi dari hasil observasi adalah indikator un-obtrusive measure. Dengan un-obtrusive measure ini peneliti dapat memperoleh suatu gambaran pola prilaku subyek yang sedang diteliti dengan berdasarkan pada kondisi atau lingkungan dimana subyek yang sedang diteliti menjadi bagian dirinya.

\section{Interview}

Penggunaan metode ini menunjukkan terjadinya komunikasi timbal balik antara peneliti dengn subyek yang diteliti. Metode interviu digunakan untuk mendukung data yang telah dikumpulkan melalui partisipan observasi dan non-partisipan observasi. Interviu yang sering digunakan dalam penelitian dapat diklasifikasikan atas interview berstruktur dan tidak berstruktur. interview berstruktur tepat digunakan dalam penelitian kuantitatif karena semua pertanyaan telah digiring oleh pola tertentu untuk menjaring data yang diharapkan. Sedangkan interview tidak berstruktur memberi kebebasan kepada peneliti untuk menentukan ruang lingkup informasi yang akan digali sehingga peneliti mempunyai kebebasan 
untuk memperluas atau merubah pertanyaan yang akan dikemukakan kepada subyek penelitian.

Tujuan dilakukan wawancara disamping mendukung data yang telah dikumpulkan melalui observasi partisipan dan non-partisipan adalah memperoleh konstruksi yang terjadi sekarang tentang orang, kejadian, aktivitas, organisasi, perasaan, motivasi, pengakuan, kerisauan, rekonstruksi keadaan tersebut berdasarkan pengalaman masa lalu, proyeksi keadaan tersebut untuk masa yang akan datang, verifikasi, pengecekan dan pengembangan informasi yang telah didapat sebelumnya

\section{Documentasi}

Penggunaan dokumentasi dilakukan untuk mengumpulkan data dari sumber dokumen dan rekaman. Dokumentasi digunakan dengan alasan karena sumber ini selalu tersedia dan murah, kaya secara kontekstual, relevan serta mendasar dalam konteksnya.

Dokumen yang dapat digunakan dalam penelitian kualitatif adalah : (1) dokumen pribadi, seperti : buku harian, surat pribadi, outo biografi, (2) dokumen resmi terdiri dari dokumen internal seperti memo, pengumuman, instruksi, aturan, rekaman hasil rapat dan keputusan pimpinan, dokumen eksternal seperti bahan informasi 
yang dihasilkan lembaga sosial, misalnya majalah, buletin berita media massa dan sebagainya.

Keabsahan data yang telah dikumpulkan dalam penelitian kualitatif perlu dilihat dengan cara tertentu. Maleong (1998:187) menjelaskan keabsahan data merupakan konsep penting yang dipengaruhi dari konsep kesahihan (validitas) dan keandalan (reliabilitas) menurut versi positivistime dan disesuaikan dengan tuntutan pengetahuan, kriteria dan paradigma penelitian kualitatif sendiri. Validitas dan reliabilitas dalam paradigma positivistik bila tidak dilakukan dengan tepat dan benar serta hati-hati akan menjadi ancaman terhadap pengontrolan hasil penelitian. Sehubungan dengan hal itu, Kirk dan Miller (1982 : 21) menjelaskan tidak ada satupun studi eksperimen yang dapat dikontrol secara tepat dan tidak ada instrumen pengukuran yang dapat diklabirasi secara akurat. Ini berarti bahwa banyak kelemahan dan penggunaan ukuran validitas dan reliabilitas pada tinjauan kacamata non kualitatif.

Penelitian kualitatif dengan paradigma naturalistik tidak menggunakan kriteria validitas dan reliabilitas tersebut. Lincoln dan Guba (1981:294) menjelaskan dasar kepercayaan yang berbeda akan mengarah pada tuntutan pengetahuan (Knowledge) dan kriteria yang berbeda pula. 
Oleh karena itu kriteria dan teknik pemeriksaan keabsahan data dalam penelitian kualitatif berbeda dengan kuantitatif.

Kriteria keabsahan data yang digunakan dalam penelitian kualitatif adalah derajat kepercayaan (credibility), keteralihan (transferability), ketergantungan (dependability) dan kepastian (confirmality). Penerapan kriteria derajat kepercayaan pada dasarnya menggantikan konsep validitas internal dari penelitian non kualitatif. Kriteria ini berfungsi : (1) melaksanakan inkuiri sedemikian rupa sehingga tingkat kepercayaan penemuannya dapat dicapai, (2) mempertunjukkan derajat kepercayan hasil-hasil penemuan dengan jalan pembuktian oleh peneliti pada kenyataan ganda yang sedang diteliti.

Kemudian keteralihan sebagai persoalan empiris bergantung pada kesamaan antara konteks pengirim dan penerima informasi. Untuk melakukan pengolahan tersebut peneliti hendaknya mencari dan mengumpulkan kejadian empiris tentang kesamaan konteks suatu informasi. Dengan demikian peneliti bertanggung jawab untuk menyediakan data deskriptif secukupnya jika dia ingin membuat keputusan tentang pengalihan tersebut. Untuk keperluan itu peneliti harus memastikan usaha menverifikasi informasi tersebut. 
Kriteria ketergantungan, merupakan substitusi istilah reliabilitas dalam penelitian non kualitatif. Pada cara non kualitatif, reliabilitas ditunjukan dengan cara, jika dua data beberapa kali diadakan pengulangan suatu studi dalam kondisi yang sama dan hasilnya secara essensial sama, maka dikatakan reliabilitasnya tercapai. Konsep ketergantungan lebih luas dari reliabilitas, hal ini disebabkan karena peninjauannya dari segi konsep ketergantungan memperhitungkan segala-galanya, yaitu yang ada pada reliabilitas itu sendiri ditambah faktor-faktor lainnya. Untuk itu dilakukan pemeriksaan yang dilakukan orang lain, misalnya data dapat dipahami dan dibaca oleh orang lain (orang tersebut diharapkan menaruh perhatian untuk mereview aktifitas peneliti secara objektif).

Analisis data dalam penelitian kualitatif dilakukan selama proses dan akhir pengumpulan data. Salah satu alternatif kerangka laporan penelitian kualitatif dapat digunakan kerangka sebagai berikut :

\section{Bagian Awal}

- Halaman Judul

- Abstrak

- Kata Pengantar

- Daftar Isi 
- Daftar Tabel

- Daftar Gambar

- Daftar Lampiran

\section{Bagian Inti}

\section{BAB I. PENDAhULUAN}

Bagian ini memaparkan gambaran umum arah penelitian, sehingga melalui hal itu diketahui latar belakang, fokus, tujuan, landasan teori serta kegunaan penelitian.

\section{Latar Belakang Penelitian}

Bagian latar belakang menggambarkan secara utuh dan menyatu tentang: tema sentral masalah yang dikaji, mekanisme proses timbulnya masalah tersebut, motivasi yang mendasari dilakukan penelitian dan harapan yang diinginkan dari pelaksanaan penelitian.

Tema sentral masalah yang menjadi kajian dalam penelitian bersifat kondisional atau situasional yang didalamnya terdapat tantangan, tuntutan dan kesempatan. Sehubungan dengan hal itu tidak jarang dalam pengungkapan tema sentral masalah penelitian diungkapkan terlebih dahulu fenomena atau gejala yang dihadapi serta akibatnya. Kehangatan , aktualitas serta relevansi perlu menjadi bahan pertimbangan. 
Mekanisme timbulnya masalah yang diungkapkan dalam latar belakang masalah juga memaparkan proses terjadinya masalah dari awal sampai dewasa ini yang belum tersentuh secara lengkap dan utuh dalam suatu bidang ilmu sehingga menjadi masalah dalam kehidupan manusia.

\section{Rumusan Masalah (Fokus Penelitian)}

Pokok permasalahan atau fokus penelitian ditentukan dengan memilih pokok permasalahan (fokus penelitian) yang diungkapkan pada awalnya sangat umum dan berlanjut kepada uraian yang lebih bersifat spesifik. Fokus penelitian menggambarkan rincian pernyataan atau topik-topik pokok yang akan diungkapkan melalui penelitian. Apabila digunakan rumusan masalah fokus penelitian berisi pernyataan-pernyataan yang akan dijawab dalam penelitian dan alasan diajukannya pernyataan. Pernyataan-pernyataan ini diajukan untuk mengetahui gambaran apa yang akan diungkapkan di lapangan.

\section{Tujuan Penelitian}

Tujuan penelitian merupakan sasaran hasil yang ingin di capai dalam penelitian ini sesuai dengan fokus yang telah dirumuskan.Tujuan penelitian dirumuskan secara utuh dan berorientasi kepada pertanyaan-pertanyaan 
dalam permasalahan (fokus penelitian). Dari tujuan penelitian tercermin langkah operasional penelitian yang akan dilakukan.

\section{Kegunaan Penelitian}

Kegunaan penelitian ditujukan untuk pengembangan ilmu dan berguna dalam pelaksanaan pembangunan. Melalui paparan ini dapat disimpulkan bahwa permasalahan yang diteliti layak dilaksanakan dan fungsional secara ilmiah dan praktis.

\section{BAB II. KAJIAN PUSTAKA}

Kajian kepustakaan berfungsi sebagai dukungan, evidensi ilmiah yang relevan dengan masalah yang diteliti. Kajian teori bermanfaat sebagai pemandu agar fokus penelitian sesuai dengan kenyataan di lapangan. Di samping itu landasan teori bermanfaat untuk memberikan gambaran umum tentang latar penelitian dan sebagai bahan pembahasan hasil penelitian. Peran landasan teori dalam penelitian kualitatif jauh berbeda dengan penelitian kuantitatif. Penelitian kuantitatif berangkat dari teori ke data serta berakhir pada penolakan atau penerimaan teori yang diajukan. Sedangkan penelitian kualitatif peneliti bertolak dari data, memanfaatklan teori sebagai bahan penjelas dan berakhir dengan suatu teori. 


\section{BAB III. METODE PENELITIAN}

Bagian ini memaparkan tentang metode serta langkah-langkah penelitian secara operasional, meliputi pendekatan, kehadiran peneliti, lokasi penelitian sumber data, prosedur pengumpulan data, analisis data, pengecekan keabsahan data serta tahap-tahap penelitian.

\section{Pendekatan dan Jenis Penelitian}

Penjelasan tentang pendekatan dan alasan pemilihan, orientasi teoritik sebagai dasar berfikir memahami makna dari suatu fenomena serta jenis penelitian. Pendekatan yang digunakan yaitu pendekatan kualitatif. Sedangkan orientasi teoritik yang dapat digunakan dalam penelitian kualitatif adalah fenomenologis, interaksi simbolik, kebudayaan, etnometodologis serta hermeneutik. Jenis penelitian yang dapat digunakan yaitu : etnografis, studi kasus, grounded theory, interaktif, ekologis, partisipatoris dan sebagainya.

\section{Kehadiran Peneliti}

Peneliti bertindak sebagai instrumen utama oleh karena itu kehadiran peneliti di lapangan dalam penelitian kualitatif mutlak diperlukan. Instrumen lain selain peneliti dapat dilakukan tetapi fungsinya hanya sebagai pendukung data yang telah dikumpulkan peneliti. Kehadiran peneliti apakah diketahui sebagai peneliti oleh subyek penelitian atau tidak perlu dijelaskan secara rinci 
dalam laporan. Begitu juga tingkat keterlibatan peneliti selama proses pengumpulan data apakah melakukan partisipan utuh, pengamat partisipan atau pengamat utuh.

\section{Lokasi Penelitian}

Paparan tentang lokasi penelitian menyangkut dengan identifikasi karakteristik lokasi, alasan memilih lokasi serta cara peneliti memasuki lokasi tersebut. Uraian tentang lokasi juga dilengkapi dengan letak geografis, bangunan fisik (peta), struktur organisasi, program, serta keadaan keseharian. Lokasi dipilih didasari oleh keunikan, kemenarikan serta kesesuaian dengan permasalahan yang sedang dikaji. Semua hal itu perlu mendapatkan penjelasan secara rinci.

\section{Sumber Data}

Bagian ini dipaparkan data yang dikumpulkan, karakteristik serta subjek dan informan penelitian, teknik mengumpulkan data, teknik yang digunakan untuk menjamin kredibilitas data, pengambilan sampel. Pengambilan sampel dalam penelitian kualitatif dikenakan pada situasi, subyek, informan dan waktu. Tujuan pengambilan sampel dalam kualitatif adalah mendapatkan informasi sebanyak mungkin . 


\section{Analisis Data}

Bagian ini diuraikan proses pelacakan dan pengaturan secara sistematis transkrip-transkrip wawancara, catatan lapangan dan bahan lain agar peneliti dapat menyajikan temuannya. Kegiatan yang dilakukan dalam proses analisis data menyangkut pelacakan, pengorganisasian, pemecahan dan sintesis data serta pencarian tema/pola/proposisi serta penentuan hal-hal yang akan dilaporkan. Analisis data dalam penelitian kualitatif dilakukan selama proses pengumpulan data dan setelah pengumpulan data berakhir. Teknik analisis dapat menggunakan pendekatan yang diajukan Spradley, Milles, Paton, Staus Corbin dengan langkah masing-masing yang mereka ajukan.

\section{Pengecekan Keabsahan Data}

Untuk memperoleh keabsahan temuan, perlu diteliti kredibilitas data dengan menggunakan teknik perpanjangan kehadiran peneliti di lapangan, observasi yang diperdalam, trianggulasi (dapat dilakukan trianggulasi sumber, metode, peneliti dan teori), pengecekan sejawat, analisis kasus negatif, pengecekan kesesuaian hasil, memberchek. Disisi lain perlu dilakukan pengecekan dapat atau tidaknya data ditransfer ke latar penelitian lain (transferability), ketergantungan pada konteks (Dependability) dan dapat tidaknya dikonfirmasikan kepada sumber (Confirmability). 
Tahap Penelitian

Tahap penelitian dalam penelitian kualitatif diuraikan denganmemaparkan proses pelaksanaan penelitian yang diawali dengan penelitian pendahulkuan, penyusunan proposal, pengembangan desain, pengumpulan data dan analisis data serta penulisan laporan.

\section{BAB.IV. TEMUAN DAN PEMBAHASAN}

\section{Temuan Penelitian}

Temuan penelitian berisikan paparan data yang diperoleh dari pengamatan dan wawancara serta hasil deskripsi lainnya. Sedangkan hasil analisis data sebagai temuan disajikan dalam bentuk pola, tema, kecenderungan yang muncul dari data. Disisi lain temuan dapat disajikan dalam bentuk kategori, sistem klasifikasi dan tipologi.

\section{Pembahasan}

Bagian ini menggambarkan gagasan peneliti yang berkaitan dengan pemaknaan temuan penelitian dengan pola-pola, kategori-kategori, dimensidimensi dan teori-teori yang sudah ada. Selanjutnya bagian ini perlu dilengkapi dengan implikasi temuan yang sudah diperoleh dari penelitian. 


\section{BAB. V. KESIMPULAN DAN SARAN \\ Kesimpulan}

Bagian kesimpulan memuat makna pokok dari temuan sesuai dengan fokus yang sudah diajukan pada bagian pendahuluan.

Saran

Saran memuat rekomendasi, implikasi serta tindak lanjut sesuai dengan hasil temuan yang sudah diperoleh terhadap pengembangan ilmu pengetahuan serta penggunaan praktis.

\section{Penelitian Kuantitatif}

Penelitian kuantitatif berbeda dengan penelitian kualitatif. Penelitian kuantitatif menghasilkan informasi yang lebih terukur. Hal ini karena ada data yang dijadikan landasan untuk menghasilkan informasi yang lebih terukur.

Penelititan kuantitatif tidak mempermasalahkan hubungan antara peneliti dengan subyek penelitian karena hasil penelitian lebih banyak tergantung dengan instrumen yang digunakan dan terukur variabel yang digunakan, dari pada intim dan keterlibatan emosi antara peneliti dengan subyek yang diteliti. 
Borg dan Gall (1989) mengidentifikasi bahwa penelitian kuantitatif terdiri dari penelitian eksploratif dan penelitian sebab akibat (causal). Penelitian eksplioratif lebih menekankan kepada upaya menggabarkan situasi. Kerlinger (1986) membedakan penelitian kuantitatif menjeadi penelitian eksperimen dan penelitian non-eksperimen. Dwengan menggunakan kerangka yang digunakan olehg Borg dan Gall, nampaknya Kerlinger tidak mempertimbangkan penelitian eksploratif sebagai salah satu bentuk penelitian kuantitatif.

Pembahasan ini akan mengkategorikan penelitian kuantitatif menjadi dua, yaitu penelitian eksploratif dan penelitian causal. Lebih lanjut penelitian sebab akibat menjadi penelitian eksperimen dan non eksperimen. Sebagai dikemukakan di atas, meskipun penelitian kuantitatif berbeda jenisnya, akan tetapi diantara penelitian kuantitatif yang berbeda tersebut mempunyai beberapa ciri yang sama, yaitu sampel merupakan dasar dalam menggambil kesimpulan dan kedua ketepatan dalam penggunaan instrumen dan dalam mengukur variabel merupakan indikator utama untuk mengukur.

\section{a. Penelitian Eksploratif}

Penelitian eksploratif merupakan sarana yang efektif untuk memberikan gambaran keadaan sosial tertentu. Meskipun demikian, 
para peneliti yang bertujuan untuk melakukan pembuktian hipotesis penelitian eksploratif bukan merupakan sarana yang tepat, karena kecenderungan pada penelitian eksploratif hanya mendeskripsikan kecenderungan satu variabel tanpa mempertimbangkan atau mengontrol variabel lainnya. Di lain pihak penelitian yang dimaksud untuk menguji hipotesis, analisis data tidak hanya dilakukan dengan memperkirakan hubungan antar dua variabel. Pembuktian hipotesis pada dasarnya didasarkan kepada hubungan non-spurious. Hal ini bisa dilakukan dengan proses elaborasi yaitu mengontrol beberapa variabel lainnya. Dilain pihak penelitian yang dimaksudkan untuk menguji hipotesa, analisis data tidak saja dilakukan dengan hanya memperkirakan hubungan antar dua variabel. Pembuktian hipotesa pada dasarnya didasarkan pada hubungan non sprious. Hal ini bisa dilakukan dengan proses elaborasi yaitu mengontrol beberapa variabel yang diduga mempunyai pengaruh terhadap hubungan dua variabel yaitu variabel independen dan variabel dependen.

Pada penelitian eksploratif metode yang digunakan adalah analsis frekwensi satu variabel. Dengan demikian, hasil analisis adalah kecendrungan satu variabel. Meskipun demikian, masih banyak penelitian di Indonesia tentang coherence antara lain analisis data 
dengan kesimpulan yang diambil berdasarkan pada hasil analisis. Akibatnya, adalah peneliti tersebut mengambil kesimpulan melebihi daripada informasi berdasarkan temuan penelitian.

Analisis data dengan menggunakan data tabulasi silang pada derajat tertentu dapat digunakan untuk mengukur sebab akibat, tetapi daya prediksinya tidak sekuat hasil analisis statistik.

\section{b. Penelitian Kausal}

Meskipun ada salah satu bentuk penelitian yang di desain untuk menjelaskan hubungan antar variabel, tetapi kesimpulan yang bersifat kausal tidak bisa didasarkan pada simplicity. Artinya bahwa dengan hanya berdasarkan pada perhitungan statistik yang signifikan kemudian peneliti bisa mengambil kesimpulan kausalistik dari dua variabel atau lebih.

Kesimpulan tentang hubungan kausalistik dari dua variabel atau lebih berlangsung melalui empat tahap yaitu : (1) tahap konseptual, (2) tahap pengukuran variabel, (3) tahap seleksi sampel dan (4) tahap manipulasi matematis. Keempat tahap ini merupakan satu kesatuan yang harus dipenuhi kalau kesimpulan kausalistik menjadi tujuan.

Oleh karena itu meskipun penelitian berikut ini tergolong pada penelitian kausal, namun dalam mengambil kesimpulan bersifat 
kausalistik harus mempertimbangkan keempat tahap tersebut. Tanpa mempertimbangkan keempat tahap tersebut, peneliti telah mengambil oversimplified conclusion. Kesimpulan semacam ini kurang mempunyai arti bagi pengembangan ilmu pengtahuan.

Seperti telah disebutkan di atas, penelitian yang tergolong pada penelitian kausal adalah penelitian eksperimen dan penelitian non eksperimen. Lebih populernya penelitian non eksperimen ini disebut sebagai penelitian survey.

Perbedaan prinsip antara penelitian eksperimen dan non eksperimen adalah terletak pada kemampun peneliti dalam mengontrol perlakuan yang diberlakukan pada subjek penelitian. Pada penelitian eksperimen. Peneliti mempunyai kontrol terhadap perlakuan yang diberikan kepada subjek penelitian. Sedangkan pada penelitian suvey tidak.

Jika ada hipotesa yang menyebutkan bahwa jika X dan $Y$, maka ada penelitian non eksperimen peneliti hanya mengumpulkan data tentang kecendrungan pada $\mathrm{X}$ an $\mathrm{Y}$ dan kemudian memperkirakan derajat kovariasi yang tinggi, maka peneliti mempunyai satu prasyarat untuk mengatakan jika $\mathrm{X}$ dan $\mathrm{Y}$. Di lain pihak, bagi penelitian eksperimen, dalam menguji hipotesa tersebut, maka peneliti akan 
mengukur variasi pada variabel $Y$ dan kemudian memanipulasi variabel $\mathrm{X}$ dan kemudian melihat derajat kovariasi antara $\mathrm{X}$ dan Y. Jika terdapat derajat kovariasi yang tinggi maka perlakuan yang dikenakan kepada variabel $\mathrm{X}$ yang menyebabkan terjadinya kovarias antara $\mathrm{X}$ dan $\mathrm{Y}$.

Perbedaan lain yang membedakan antara keduanya adalah pada penelitian eksperimen didasarkan pada asumsi equality dari kelompok-kelompok yang akan dibandingkan. Bahwa sebelum diberikan perlakuan kelompok-kelompok yang akan diteliti harus dalam kondisi sederajat, yang menjadikan mereka tidak sederajat adalah karena perlakuan yang diberikan oleh peneliti.

Pada penelitian non eksperimen perlakuan sudah diasumsikan terjadi, jadi asumsi equality tidak berlaku. Hasil analisis yang menunjukkan bahwa kelompok yang satu mempunyai karakteristik tertentu, sedangkan kelompok lainnya tidak.

\section{E. Penutup}

Perbedaan paradigma penelitian kuantitatif dengan kualitatif menyebabkan proses dan hasil penelitian kedua pendekatan tersebut berbeda. Walaupun demikian untuk menentukan kebenaran secara ilmiah kedua pendekatan tidak jarang dilakukan secara bersamaan. 


\section{DAFTAR PUSTAKA}

Anderson, J.A. (1984) Public Policy - Making. Edisi ke Tiga. Holt, Rinehart and Winston, Inc

Alkin, M.C. (1985). A Guide for Evaluation Decision Makers. Baverly Hills : Sage

Borg, W.R. and Gall M.D. (1989). Educational Research. Edisi kelima. New York. New York : Longman.

Brewer, G.D \& de leon. P. (1983). The Foundation of policy Analysis. Pacific Groove, C.A : Brook / Cole Publishing Company

Cooley, W.. \& Bickel, W. (1986). Decision Oriented Educational Research. Boston : Kluwer - Nijhoff Publishing

Direktorat Jenderal Pendidikan Tinggi, (1989). Petunjuk Pelaksanaan Pengelolaan Penelitian di Direktorat Jenderal Pendidikan Tinggi. Jakarta : Dirjen Dikti

Dye, T.R. (1984), Understanding Public Policy. Edisi ke Empat. Englewood Cliffs. N.J : Prentice - Hall. Inc. 